\section{Dorota Lagodzka}

Uniwersytet Warszawski

\title{
Podmiotowość zwierząt w sztuce ${ }^{1}$
}

\section{Abstract \\ Animal Subjectivity in Art}

This article aims to give a theoretical overview of the problem of animal subjectivity in visual arts. The author presents the ways of understanding the concept of the animal subject in philosophy, animal psychology, ethology and law, pointing out its special character in the field of art. The text includes a succinct description of changes in the depiction of animals in the course of art history, explaining the connections between the subjectification and objectification of animals in art versus the real human-animal relations. The second half of the $20^{\text {th }}$ century is recognized as the time when animal subjectivity in art changed the most dramatically, as artists began using real animals as participants in their art and their dead body parts as materials. Looking into both the art with animal imagery and the one that uses real animals, the author notices connections between symbolism and instrumentalization which take animals away from becoming subjects. Using the zoocentric research perspective of Éric Baratay, Łagodzka analyzes animal subjectification and objectification in the process of art perception.

Słowa kluczowe: sztuki wizualne, zwierzęta w sztuce, animal studies, antropozoologia, podmiot, podmiotowość zwierząt

Keywords: visual arts, animals in art, animal studies, anthrozoology, subject, animal subjectivity

1 Projekt sfinansowany ze środków Narodowego Centrum Nauki przyznanych na podstawie decyzji numer DEC-2013/11/S/HS2/03313. 


\section{Pojęcie zwierzęcej podmiotowości}

Bogata tradycja refleksji filozoficznej nad podmiotowością w niewielkim stopniu dotyczy zwierząt. Dużo częściej zwierzęta lub zwierzęcość służyły jako kategoria pomagająca zrozumieć ludzką naturę, kondycję czy tożsamość. Jedną z najwcześniejszych prób opracowania zwierzęcej podmiotowości podjął biolog i filozof biologii Jacob von Uexküll, stwarzając teorię wokółświatów². Próby opracowania pojęcia zwierzęcego podmiotu czerpią z analiz zdolności poznawczych zwierząt, dokonywanych przez przedstawicieli kognitywistyki, etologii, zoopsychologii i prymatologii. Nieodzowne dla rozumienia podmiotowości zwierząt są koncepcje z zakresu etyki zwierzęcej (animal ethics) i teorii praw zwierząt, od wczesnoutylitarystycznego ujęcia Jeremy'ego Benthama $^{3}$ przez klasyczne już teorie Petera Singera ${ }^{4}$ i Toma Regana ${ }^{5}$ po różnorodność podejść przedstawionych w zbiorze The Animal Ethics Reader ${ }^{6}$, a po części także w krytycznym kompendium Doroty Probuckiej Filozoficzne podstawy praw zwierząt ${ }^{7}$. Autorka analizuje w nim m.in. podejście Gary'ego Francione' $a^{8}$, jedno z najnowszych dotyczących teorii praw zwierząt.

Rozważania w ramach filozofii zwierzęcej (animal philosophy) - m.in. Cary'ego Wolfe' $a^{9}$, Matthew Callarca ${ }^{10}$ i Petera Attertona ${ }^{11}$ - dostarczają z kolei analiz różnorodnych pojęć zwierzęcia i zwierzęcości funkcjonujących w ramach poszczególnych dyskursów i tradycyjnych koncepcji filozo-

2 J. von Uexküll, Biologia lub fizjologia, przeł. A. Pobojewska, M. Półrola, „Przegląd Filozoficzno-Literacki” 2011, nr 2-3 (31), s. 19-26.

3 J. Bentham, Wprowadzenie do zasad moralności i prawodawstwa, przeł. B. Nawroczyński, Warszawa 1958.

4 Zob. m.in. P. Singer, Wyzwolenie zwierząt, przeł. A. Alichniewicz, A. Szczęsna, Warszawa 2004.

5 Zob. m.in. T. Regan, The Case for Animal Rights, Philadelphia 1983; idem, Defending Animal Rights, Urbana-Chicago 2001, oraz kilkadziesiąt innych tekstów tego autora na temat etyki praw zwierząt.

6 The Animal Ethics Reader, eds. S.J. Armstrong, R.G. Botzler, Abingdon-New York 2008. Zob. też: M. Bekoff, C.A. Meaney, Encyclopedia of Animal Rights and Animal Welfare, Westport, CT 1998.

7 D. Probucka, Filozoficzne podstawy praw zwierząt, Kraków 2013.

8 Zob. m.in. G.L. Francione, Animals, Property, and Law, Philadelphia 1995; idem, Animal Rights and Animal Welfare, New York 2005.

9 Zob. m.in. C. Wolfe, In the Shadow of Wittgenstein's Lion: Language, Ethics, and the Question of the Animal [w:] Zoontologies: The Question of the Animal, ed. C. Wolfe, Minneapolis-London 2003.

10 Zob. m.in. M. Calarco, Zoographies: The Question of the Animal from Heidegger to Derrida, New York 2008; idem, Thinking Through Animals: Identity, Difference, Indistinction, Stanford 2015.

11 Zob. m.in. Animal Philosophy: Ethics and Identity, eds. P. Atterton, M. Calarco, London-New York 2011. 
ficznych. Peter Carruthers w artykule Animal Subjectivity poddaje krytycznej analizie filozoficzne koncepcje zwierzęcej podmiotowości w nurcie reprezentacjonizmu, podkreślając znaczenie zwierzęcego doświadczenia, lecz odmawiając zwierzętom pewnej formy świadomości, którą nazywa zjawiskową (phenomenal conciousness) ${ }^{12}$. W książce Animals Subjects pod redakcją Jodey Castriciano liczni autorzy analizują różne aspekty zwierzęcej podmiotowości w odniesieniu do m.in. nowożytnego postrzegania zwierząt, posthumanizmu, teorii z zakresu genetyki, socjobiologii, kognitywistyki, teorii feministycznej, języka i mowy, moralnego statusu i pojęcia osoby ${ }^{13}$. Jacques Derrida w eseju The Animal That Therefore I Am sugeruje zwierzęcą podmiotowość przez zakwestionowanie zbyt ogólnej, jego zdaniem, kategorii „Zwierzęta”"14. David de Grazia analizuje ważne dla koncepcji podmiotowości pojęcie osoby w odniesieniu do zwierzą ${ }^{15}$.

Odrębną kwestią jest definicja zwierzęcego podmiotu w prawie stanowionym - to zagadnienie wiąże się z teorią polityczną. Status prawny zwierząt w Polsce analizował m.in. Jan Białocerkiewicz ${ }^{16}$. Andrzej Elżanowski i Tomasz Pietrzykowski pisali zaś o zwierzętach jako nieosobowych podmiotach prawa $^{17}$. Polityczną teorię praw zwierząt, w której ważne są pojęcia podmiotowości i jednostkowości, przedstawiają w książce Zoopolis Sue Donaldson i Will Kymlicka, proponując włączenie zwierząt do obywatelskiej wspólnoty ${ }^{18}$. Posthumanistyczne koncepcje płynnej podmiotowości, np. Rosi Braidotti ${ }^{19}$, obejmują z kolei zazwyczaj na tyle szeroką gamę organizmów żywych lub

12 P. Carruthers, Animal Subjectivity, „PSYCHE”, April 1998, no. 4 (3). Zob. też: idem, Suffering without Subjectivity, „Philosophical Studies” 2004, vol. 121, no. 2, s. 99-125. 2008 .

13 J. Castriciano, Animal Subjects: An Ethical Reader in a Posthuman World, Ontario

14 J. Derrida, The Animal That Therefore I Am, eds. M.-L. Mallet, trans. D. Wills, New York 2008.

15 D. de Grazia, O byciu osoba poza gatunkiem Homo sapiens [w:] W obronie zwierzat, red. P. Singer, przeł. M. Betley, Warszawa 2011, s. 63-80.

16 J. Białocerkiewicz, Status prawny zwierząt. Prawa zwierząt czy prawna ochrona zwierząt, Toruń 2005.

17 A. Elżanowski, T. Pietrzykowski, Zwierzęta jako nieosobowe podmioty prawa, „Forum Prawnicze", luty 2013, s. 18-27.

18 S. Donaldson, W. Kymlicka, Zoopolis: A Political Theory of Animal Rights, New York 2011.

19 Zob. m.in. R. Braidotti, Po człowieku, przeł. J. Bednarek, A. Kowalczyk, Warszawa 2014; eadem, Etyka stawania się niewykrywalnym, przeł. J. Bednarek [w:] Teorie wywrotowe. Antologia przekładów, red. A. Gajewska, Poznań 2012, s. 289-322; D. Haraway, Manifest gatunków stowarzyszonych, przeł. J. Bednarek [w:] Teorie wywrotowe..., s. 242-260. 
w ogóle bytów, że nie są w stanie uchwycić specyfiki zwierzęcych podmiotów, pomagają jednak zrozumieć, dlaczego dyskusja o podmiotowości zwierząt innych niż ludzie jest nie tylko uzasadniona, lecz także nieunikniona ${ }^{20}$.

Powyższe wyliczenie nie uwzględnia oczywiście wszystkich teorii zwierzęcego podmiotu. Ma ono służyć jedynie naszkicowaniu tła dla rozważań nad zwierzęcą podmiotowością w sztuce. Wspomniane powyżej teorie mogą okazać się przydatne przy interpretacji poszczególnych dzieł. Można je też odnieść do zwierząt w sztuce, jeśli potraktuje się ją jako jedną z ludzkich aktywności. Żadna z tych koncepcji nie porusza jednak specyfiki podmiotowości zwierząt w twórczości artystycznej jako unikatowej formie działania, polegającej na wytwarzaniu szczególnych obiektów, wizerunków, kontekstów i znaczeń. Teksty o zwierzętach w sztuce i kulturze wizualnej przywołują z kolei wybrane koncepcje filozoficzne zwierzęcego podmiotu, lecz nie precyzują tego pojęcia w odniesieniu do szczególnego, artystycznego kontekstu kształtowania się ontycznego statusu ${ }^{21}$. Spróbuję więc opisać teoretycznie, na czym polega podmiotowość zwierząt w sztuce rozumianej jako obszar, który operuje wizualną reprezentacją ustanawiającą dodatkowy wymiar istnienia zwierząt, jako ludzka działalność w jej dosłownym, materialnym wymiarze wytwarzania obiektów artystycznych lub działania artystycznego oraz jako relacja między obiektami a postaciami i ich wizerunkami.

Przyjmuję perspektywę, którą nazywam zoocentryczną. Ten tekst nie jest jednak próbą usytuowania zoocentryzmu względem nowych koncepcji i metod badawczych odchodzących od paradygmatu antropocentrycznego. Odsyłając więc czytelnika do posthumanizmu, biohumanistyki, humanistyki ekologicznej, a przede wszystkim studiów nad zwierzętami (animal studies) i antropozoologii (anthrozoology), postaram się nakreślić perspektywę zoocentryczną w takim zakresie, w jakim stosuję ją w tym tekście. Polega ona na dystansowaniu się od tradycyjnych, antropocentrycznych sposobów badania sztuki i przeniesieniu głównego zainteresowania z ludzi na zwierzęta innych gatunków. W takim spojrzeniu na sztukę zwierzętom zostaje przyznane znaczenie, uznawane są one za ważne w sensie ontologicznym, epistemologicznym i aksjologicznym. Zoocentryczne interpretacje sztuki nie negują dotychczasowych interpretacji, lecz pozwalają dostrzec w dziełach coś innego miejsce zwierzęcia lub zwierząt $w$ strukturze wizualnej dzieła $i$ jego treści.

Za pomocną uznaję metodę badań historycznych Érica Barataya, który opisuje historię z perspektywy sprawczych zwierzęcych podmiotów. Zastosowanie przeze mnie metody inspirowanej podejściem tego francuskiego ba-

20 Zob. m.in. R. Braidotti, Po człowieku...; eadem, Etyka stawania się niewykrywalnym..., s. 289-322; D. Haraway, op.cit., s. 242-260.

21 Zob. m.in. G. Aloi, Art and Animals, London-New York 2012; S. Baker, The Postmodern Animal, London 2000; idem, Artist/Animal, Minneapolis-London 2013; R. Broglio, Surface Encounters: Thinking with Animals and Art, Minneapolis-London 2011. 
dacza ma jednak inny cel - badania nie historii, lecz sztuki, co więcej - jej współczesnych znaczeń. Postrzeganie zwierząt jako podmiotowych istot żywych jest podstawą zoocentrycznej perspektywy badań, zarówno nad historią, jak i sztuką, przy czym wiedza historyczna może służyć jako pomoc w interpretacji sztuki. Nie utożsamiam jednak zoocentryzmu z metodą Barataya i stosuję ją głównie w części tekstu poświęconej wytwarzaniu podmiotowości w procesie odbioru dzieł sztuki.

Wracając do pojęcia zwierzęcego podmiotu poza specyficznym kontekstem sztuki, można zadać pytanie, czy podmiotowość jest stopniowalna, czy zwierzę może być podmiotem w jakimś stopniu, częściowo bądź połowicznie. Idąc tropem rozumowania de Grazii na temat osobowego statusu zwierzą̧ ${ }^{22}$, odpowiedziałabym na to pytanie twierdząco, zaznaczając, że są sytuacje, w których możemy mieć pewność co do podmiotowego statusu danego bytu, lecz zdarzają i takie, w których tę pewność tracimy i narzuca się poczucie jego podmiotowej niepełności. Wtedy z kolei nasuwają się inne pytania: Czy warunkiem bycia podmiotem jest posiadanie zestawu określonych cech? Czy mogą to być różne zestawy cech? Czy dana istota musi wykazywać wszystkie cechy dystynktywne podmiotowości, by być podmiotem, czy wystarczy, że ma tylko część z nich? Czy podmiotem można się stać lub można podmiotowość stracić, ponieważ nie jest ona trwała, dana na zawsze?

Stawiam hipotezę, że zwierzęta na przestrzeni dziejów zbliżały się do bycia podmiotami w sztuce lub oddalały się od niego, przy czym można zaobserwować pewne ogólne tendencje wskazujące na to, że w różnych okresach historycznych ich podmiotowość objawiała się z różnym natężeniem w poszczególnych realizacjach artystycznych. Ponadto zwierzęta w dziełach sztuki mogą się do podmiotowości zbliżać lub ją tracić w procesie odbioru i interpretacji.

Zarysowane w tej hipotezie płynne rozumienie podmiotowości wydaje się adekwatne także w odniesieniu do gatunków istot zwierzęcych przedstawianych przez artystów. W sztuce możemy bowiem zaobserwować całe bogactwo organizmów należących do biologicznej kategorii, jaką jest królestwo zwierząt: wizerunki istot należących do rożnych gatunków mających cechy, które zbliżają je do bycia podmiotami doznaniowymi - w znaczeniu posiadania przez nie zdolności poznawczych i zdolności do odczuwania - lub cechy, które je od tego stanu oddalają. Trudno jest zatem mówić o ogólnej podmiotowości wszystkich zwierząt innych niż ludzie z powodu ich ogromnego zróżnicowania pod względem cech decydujących o uzyskaniu statusu podmiotu. Taksonomia biologiczna porządkuje poniekąd płynność organizmów, oddziela i wyróżnia różne ich grupy; można uznać, że pomaga określić przynależność przedstawicieli gatunków do kategorii istot podmiotowych. Zawsze jednak mamy do czynienia z sytuacjami granicznymi i dylematami „mniej - bardziej”.

22 D. de Grazia, op.cit. 
Według takiego rozumowania i zgodnie ze stanem obecnej wiedzy naukowej np. kręgowce będą prawdopodobnie istotami bardziej podmiotowymi niż owady lub mięczaki, a naczelne i ptaki bardziej niż płazy. Niemniej stan naszej wiedzy jest dynamiczny, kolejne odkrycia mogą zatem wymusić zmiany w postrzeganiu podmiotowości istot żywych. Za przykład mogą posłużyć ośmiornice, które dopiero niedawno uznano za organizmy dużo bardziej złożone, niż dotychczas sądzono ${ }^{23}$. Ponadto takie kategoryzacje mogą być kwestionowane przez niektóre teorie praw zwierząt i część koncepcji z zakresu etyki zwierzęcej.

Za sprawą specyficznego kontekstu, jakim jest dzieło sztuki, jego ekspresji, referencyjności, niejednoznaczności lub kompozycji, powyższy sposób postrzegania podmiotowości zgodnie z naukowo wykazanymi zdolnościami kognitywnymi przedstawicieli poszczególnych taksonów może zostać podważony, zakwestionowany lub odwrócony. Nie staram się zatem sformułować definicji zwierzęcej podmiotowości w ogóle, lecz zaobserwować, w jaki sposób procesy upodmiotowienia lub instrumentalizacji zwierząt dokonują się za pośrednictwem medium, jakim jest sztuka. Bycie zwierzęcia w dziele sztuki wykracza bowiem poza jego zwykłe bycie w świecie.

Obecność tych istot $\mathrm{w}$ sztuce wizualnej w oczywisty sposób wydaje się zapośredniczona przez wizerunek, lecz od drugiej połowy XX wieku, kiedy to do performance'u zaczęto angażować prawdziwe zwierzęta, żywe i martwe, ich obecność w pracach artystycznych bywa także dosłowna. Podmiotowość zwierząt można zatem analizować z jednej strony w zakresie wizerunków, znaków, reprezentacji, a z drugiej - w odniesieniu do rzeczywistych istot włączonych w procesy artystyczne. Takie poszerzenie granic sztuki sprawia, że bycie $\mathrm{w}$ dziele i bycie $\mathrm{w}$ świecie na pewnym poziomie stają się tym samym. Zwierzęta mogą być tematem lub uczestnikami działań twórczych, lecz zawsze pozostają też wizerunkiem. Ramy sztuki zawsze wytwarzają nadbudowę znaczeniową ich istnienia $\mathrm{w}$ dziele $\mathrm{w}$ stosunku do ich istnienia $\mathrm{w}$ rzeczywistości pozaartystycznej. Zwierzęta, obecne w pracach cieleśnie, mogą reprezentować siebie (jako gatunek lub jednostkę) lub stanowić symbol, a zatem oznaczać coś innego, ludzkiego. Te możliwości sygnifikacyjne dotyczą również ich wizerunków: namalowana ryba może oznaczać nieżywego dorsza lub być symbolem chrystologicznym.

23 A. Abbott, Octopus Genome Holds Clues to Uncanny Intelligence, „Nature”, 12.08.2015, https://www.nature.com/news/octopus-genome-holds-clues-to-uncanny-intelligence-1.18177 [dostęp: 14.05.2018]. 


\section{Zwierzę jako temat dzieła}

„Tam, gdzie są obrazy, są i zwierzęta. [...] ludzkie kultury przeniknięte są obrazami zwierząt. Można je [zwierzęta - dop. D.Ł.] znaleźć w upolitycznionym gąszczu obrazów" - piszą Joan B. Landes, Paula Young Lee i Paul Youngquist we wstępie do książki Gorgeous Beasts: Animal Bodies in Historical Perspective $^{24}$.

Zwierzęta są w zasadzie pierwszym motywem ikonograficznym w dziejach sztuki. Były częstym tematem prehistorycznych malowideł naskalnych, rytów na kłach i rogach oraz glinianych, kostnych i brązowych figurek. W starożytności zazwyczaj miały konotacje religijne, bywały schematyczne, antropomorfizowane, realistyczne i fantastyczne, często hybrydalne, półludzkie. Popularnością cieszyły się zwierzęco-ludzkie hybrydy i zwierzęta mityczne. Średniowiecze przyniosło ogromną ilość antropomorficznych przedstawień prawdziwych i fantastycznych gatunków zwierząt, wykonujących różne przedziwne czynności, o złożonej i niejednoznacznej symbolice. Można je spotkać w bestiariuszach, na marginesach ksiąg czy w detalach architektonicznych. Zwierzęta wówczas personalizowano także poza sztuką, np. niekiedy stawiano je przed sądem. Przedstawienia rzeczywistych zwierząt $w$ realistycznych obrazach pojawiały się głównie w scenach religijnych, choćby narodzin Chrystusa, lecz ich fizjonomia bywała często zniekształcona w stosunku do rzeczywistego wyglądu gatunków.

W nowożytnej akademickiej hierarchii tematów malarskich najwyżej znajdowały się sceny mitologiczne i religijne. Zwierzęta ukazywano w scenach religijnych i mitologicznych uzasadniających ich obecność w narracji obra$\mathrm{zu}, \mathrm{np}$. w wizerunkach raju na podstawie Księgi Rodzaju, a także przedstawieniach arki Noego, Daniela w jaskini lwów czy Diany na polowaniu. Najwięcej wizerunków zwierząt można jednak znaleźć w tzw. niskich rodzajach malarstwa, czyli scenach rodzajowych i martwych naturach. Na niektórych obrazach zwierzęta stawały się jedynymi postaciami lub bohaterami pierwszoplanowymi - a w martwych naturach i scenach z kuchni także przedmiotami lecz nacechowane były symbolicznie. Konie można znaleźć na portretach i w scenach bitew, krowy w scenach wiejskich i jako sztafaż, psy w scenach rodzajowych na ulicach i we wnętrzach, ptaki i zwierzęta leśne w przedstawieniach łupów z polowań, owady, płazy, gady i bezkręgowce często były zaś ukryte w bukietach kwiatów. Od połowy XVII wieku wizerunki zwierząt rozpowszechniały się wraz z rozwojem nauk przyrodniczych, a zainteresowanie nimi wzmagało się od drugiej połowy XIX wieku wraz z recepcją teorii ewolucji i rozwojem biologii opartej na paradygmacie ewolucyjnym.

24 J.B. Landes, P. Young Lee, P. Youngquist, Introduction [w:] Gorgeous Beasts: Animal Bodies in Historical Perspective, eds. J.B. Landes, P. Young Lee, P. Youngquist, Pennsylvania 2012, s. 9 . 
Sztuka odegrała znaczną rolę w rozwoju zoologii, gdyż rysunek był ważnym narzędziem badawczym. Pod wpływem nauk przyrodniczych i wraz z rozwojem malarstwa realistycznego postacie zwierzęce uwalniały się od bagażu symbolicznego. Romantyzm przywoływał je jako część uwznioślonej przyrody. W XIX stuleciu obrazy dotyczyły relacji ludzko-zwierzęcych niż symbolicznych znaczeń. Zwierzęta coraz częściej stawały się pierwszoplanowymi postaciami, bohaterami obrazów. Upowszechniały się portrety ze zwierzętami i portrety zwierząt. W tym czasie także krajobraz uniezależniał się jako samodzielny, pełnoprawny temat malarski, co można uznać za przejaw uzyskiwania przez przyrodę podmiotowości w porządku sztuki.

W XX wieku wraz z kolejnymi awangardowymi tendencjami zwierzęta zagościły w sztuce na stałe jako samodzielny temat, choć procesy te wiązały się raczej z poszerzaniem definicji sztuki i przekraczaniem kolejnych jej granic niż zmianą stosunku do istot nie-ludzkich. W drugiej połowie stulecia (wraz z rozwojem instalacji, performance'u i filmu) nastąpiła znacząca zmiana ich statusu $\mathrm{w}$ sztuce, polegająca na wprowadzeniu rzeczywistych zwierząt do procesu twórczego i samych prac artystycznych. Żywe zwierzęta stały się współuczestnikami sztuki, a martwe jej tworzywem (mniej więcej od lat dziewięćdziesiątych także w ramach bio-artu). Zmiana ta doprowadziła do skrajnego i dosłownego uprzedmiotowienia zwierząt w sztuce, lecz także do powstania prac, których tematem było upodmiotowienie zwierząt i które sytuowały zwierzęta w pozycji podmiotów.

Ten uproszczony, szkicowy opis nie oddaje oczywiście całej złożoności zagadnienia, nie uwzględnia wyjątków i różnic geograficznych, nie zawiera wszystkich typów przedstawień i tematów. Ma jedynie na celu pokazanie dwóch zjawisk, które uznaję za ważne dla podmiotowego statusu zwierząt w sztuce. Zjawiska te to uwolnienie wizerunków zwierząt od symboliki oraz ich bezpośrednia obecność w sztuce, poza wizerunkami.

$\mathrm{W}$ języku angielskim słowo subject oznacza nie tylko podmiot w ujęciu filozoficznym jako pewnego rodzaju byt, lecz także przedmiot jako temat. To pokrewieństwo znaczeń w odniesieniu do sztuki wydaje się znaczące. Podmiotowość zwierząt wiąże się bowiem z czynieniem z nich tematu artystycznego przedstawienia. Mogą one być przedstawiane w różny sposób, lecz im bardziej są tematem dzieła, tym bardziej podmiotowy jest ich status, który zawsze stanowił część szerszego porządku o charakterze antropocentrycznym i hierarchicznym oraz przybierał rozmaite formy w zależności od stosunku do owego porządku (niekiedy bywał on także negowany).

Upodmiotowienie w sztuce związane jest również z porządkiem wizualnym $w$ ramach pracy artystycznej, $\mathrm{z}$ wizualną hierarchią postaci, a dokładniej $\mathrm{z}$ ważnością postaci zwierzęcych. Może się ono przejawiać w uczynieniu zwierzęcia tematem dzieła, niekiedy $\mathrm{w}$ zaznaczeniu jego obecności w tytule, zwłaszcza zaś w usytuowaniu go w świecie przedstawionym, w kompozycji, w strukturze pola obrazowego. Ważne okazuje się zatem to, czy zwierzę jest 
postacią główną, bohaterem przedstawienia, czy atrybutem postaci ludzkiej lub elementem tła - czy funkcjonuje jako postać pierwszoplanowa, jak bardzo jest widoczne, jak duże i czy stanowi główny temat dzieła.

Skoro dla podmiotowego statusu znaczenie ma pozycja zwierząt w przedstawionej na obrazie scenie, to warto zauważyć, że mogą one zostać pokazane jako część krajobrazu kulturowego lub naturalnego, jako ludzkie atrybuty, narzędzia pracy, materiał użytkowy. Możemy mieć do czynienia z sytuacją, gdy obraz ukazuje przedmiotowe traktowanie zwierząt, np. zagłodzone, ciężko pracujące dla człowieka, bite, umierające, zarzynane zwierzęta.

Francuski historyk Éric Baratay w książce Zwierzęcy punkt widzenia. Inna wersja historii opisuje przemiany kulturowe w Europie pod względem wzajemnych oddziaływań między ludźmi a zwierzętami ${ }^{25}$. Uchwycone przez niego historyczne przemiany ludzko-zwierzęcych relacji we Francji i innych częściach Europy są zgodne z zaobserwowanymi przeze mnie przemianami w sztuce. Zaznacza on m.in., że okres od XIX do XXI wieku to apogeum uwikłania zwierząt w ludzkie aktywności, w historię ludzkiej cywilizacji. Już od XVIII wieku zwierzęta były jednak na większą skalę i w nowy sposób zaangażowane $\mathrm{w}$ proces produkcji rolnej oraz jako siła robocza w rozwijającym się przemyśle i transporcie (procesy te straciły impet $\mathrm{w}$ wyniku rozwoju motoryzacji w XX stuleciu), a także w wojsku ${ }^{26}$. Badacz opisuje również związek wzrostu znaczenia i popularności zwierząt towarzyszących, głównie psów, sprzęgnięty z ukonstytuowaniem się nowożytnej rodziny między XVIII a XX wiekiem. Nastąpiła wówczas popularyzacja obrazu psów jako wiernych towarzyszy ludzi - od XVIII wieku wśród arystokracji i burżuazji, w XIX stuleciu także wśród mieszczaństwa - a wreszcie upowszechnienie wizerunku psa jako członka rodziny w mediach w XX wieku; zmiany te miały związek także z traktowaniem psów jako siły roboczej przez biedniejsze warstwy spoteczne ${ }^{27}$.

Procesy analizowane przez Barataya znajdują odzwierciedlenie w sztuce. Można zaobserwować analogie między opisanymi przez niego ogólnymi prawidłami przemian we wzajemnych relacjach między ludźmi a zwierzętami a miejscem zwierząt $\mathrm{w}$ sztuce. To właśnie opisywane przez Barataya gatunki i sytuacje stają się wówczas coraz częściej tematami obrazów. Okres historyczny opisany przez francuskiego historyka jako czas największego zaangażowania zwierząt $\mathrm{w}$ procesy cywilizacyjne $\mathrm{i}$ kulturowe zbiega się bowiem z pojawieniem się malarstwa realistycznego, które obrazowało codzienne życie i wypierało dominujące dotychczas sceny religijne i mitologiczne, a obok symbolicznych i alegorycznych wizerunków zwierząt coraz częściej ukazy-

25 É. Baratay, Zwierzęcy punkt widzenia. Inna wersja historii, przeł. P. Tarasewicz, Gdańsk 2014.

26 Ibidem, s. 22-29, 55-204, 269-283.

27 Ibidem, s. 30, 209-263. 
wało postacie zwierzęce reprezentujące same siebie, czyli nieoznaczające czegoś innego niż one same. Powstawało też coraz więcej obrazów, na których zwierzęta były jedynymi postaciami.

Perspektywę Barataya można odnieść do sztuki także w inny sposób: nie w zakresie nowej analizy istniejącego już dzieła, lecz w dziedzinie poszukiwań artystycznych - prób pokazania zwierzęcej perspektywy, dotarcia artystów do zwierzęcego doświadczenia. Owo podejście upowszechnia się w sztuce od lat dziewięćdziesiątych XX wieku, lecz było rzadsze i mniej oczywiste w sztuce dawnej. Takie badania również wydają mi się obiecujące, lecz nie podejmuję ich w tym tekście, ponieważ wymagałyby zastosowania metod uwzględniających elementy biografii artystów i ich wypowiedzi świadczących o stosunku do zwierząt.

\section{Upodmiotowienie w procesie odbioru dzieła}

Baratay stara się opisać historię z perspektywy zwierzęcych podmiotów. Proponuje nowe odczytanie tych samych źródeł z uwzględnieniem zwierzęcych przeżyć, zadając pytanie o osobiste doświadczenie zwierzą ${ }^{28}$. Konstytutywne dla podmiotowego postrzegania jest też odejście od uznawania ich za bierne elementy środowiska i dostrzeżenie w nich aktorów, sprawców, którzy doświadczają, reagują, działają, myślą.

Baratay zwraca uwagę, że dotychczas w badaniach historycznych zwierzę zazwyczaj umożliwiało analizę zachowań ludzkich, stanowiło pretekst do studiów, nie będąc prawdziwym przedmiotem badań ${ }^{29}$. Autor Zwierzęcego punktu widzenia wychodzi zaś od ludzkiej historii, aby wyjaśnić, jak przeżywają i odczuwają ją zwierzęta, i w ten sposób zbliżyć się do ich własnej historii ${ }^{30}$. Pisze, że choć nie da się wyeliminować ludzkiej perspektywy, to jednak można odejść od antropocentryzmu w stronę zoocentryzmu przez próbę zbliżenia się do perspektywy zwierzęcego podmiotu. Pierwszy krok to odejście od definiowania zwierząt przez brak czegoś, co posiadają ludzie.

Ważne jest, żeby przyjąć postawę empatii wobec zwierząt, widzieć i zbierać fakty w dokumentach lub przynajmniej je odgadywać, domyślać się ich. Koncept ten służy jako narzędzie metodologiczne $\mathrm{w}$ wielu naukach zajmujących się zachowaniami - takich jak psychologia, etologia ludzka, etnologia - i świadczy o woli zdecentralizowania się, by dobrze uchwycić to, co przeżywa badany podmiot $[\ldots]^{31}$.

\footnotetext{
28 Ibidem, s. 9-10.

29 Ibidem, s. 15.

30 Ibidem, s. 21.

31 Ibidem, s. 49.
} 
Baratay proponuje „odwrócić pisanie, aby nie mówić o woźnicy, który powozi, wbijającym pikę pikadorze, leczącym weterynarzu [...], karmiącym panu, lecz o ciągnącym koniu, przeszytym byku, operowanej krowie, jedzącym psie" 32 . Podobny zabieg proponuję zastosować, przynajmniej eksperymentalnie, w stosunku do sztuki, by zobaczyć, czego dotyczy dane dzieło. Dostrzeżemy wtedy obrazy o przeszywanych strzałą lub mieczem koniach, ciągnących brony wołach, czatujących na kąski ze stołu psach czy umierających w kuchni rybach.

Jednym z możliwych sposobów badania podmiotowości zwierząt w sztuce jest więc potraktowanie dzieł jak dokumentów historycznych i próba odczytania ich przy użyciu Baratayowskiej metody badania źródeł, która korzystając z nauk przyrodniczych, takich jak etologia, neurologia i zoopsychologia, próbuje odtworzyć najbardziej prawdopodobne rozumienie zwierzęcego ja. W sposób analogiczny do tego, w jaki Baratay czyta dokumenty hodowli, kopalni lub przedsiębiorstw transportowych, można czytać dzieła sztuki. Nie chodzi tu o redukcję dzieła sztuki do źródła historycznego, lecz raczej o pogłębienie lub poszerzenie interpretacji. Baratay pisze o konieczności odczytania na nowo źródeł historycznych przez porzucenie ludzkiej strony, aby przyjrzeć się stronie zwierzęcej, często rozproszonej lub ukrytej między słowami ${ }^{33}$. Podobnie dzieła sztuki domagają się ponownych analiz. Zwierzęta na obrazach mogą zostać potraktowane jak postacie, aktorzy narracji, sprawcy w świecie przedstawionym, a przez to twórcy znaczenia. Dostrzeżenie ich wizerunków i przyjrzenie się im może sprawić, że uznamy, iż obraz przedstawia coś innego, niż sądziliśmy. Jak stwierdzają Landes, Young Lee i Youngquist, obserwacja sprawia, że patrzenie jest aktem historycznym (,seeing is an act of history”). Widzenie zwierząt oznacza widzenie ich p o prze z długą, złożoną i niewidzialną historię ich reprezentacji, która je określa, sytuuje, wartościuje, dzięki czemu możemy je rozpoznać i nazwać ${ }^{34}$.

Samo ukazanie cierpienia, ubezwłasnowolnienia lub śmierci zwierząt $\mathrm{w}$ dziele sztuki, a zatem uprzedmiotowienia $\mathrm{w}$ rzeczywistości przedstawionej, może być różnie postrzegane. Chciałabym tu zwrócić uwagę na fakt, że upodmiotowienie może się też dokonać w procesie odbioru dzieła, w jego interpretacji. W sposób oczywisty percepcja sztuki jest inna niż kiedyś, te same obrazy są inaczej odbierane współcześnie niż w czasach ich powstania. To samo dotyczy postrzegania zwierząt $\mathrm{w}$ dziełach, ich odbiór wiąże się bowiem z mentalnością, wiedzą i wrażliwością widza. Ważne jest zatem, czego w dziele szukamy, z jakim nastawieniem, z jakimi pytaniami do niego podchodzimy.

\footnotetext{
32 Ibidem, s. 53-54.

33 Ibidem, s. 41-42.

34 J.B. Landes, P. Young Lee, P. Youngquist, op.cit., s. 6.
} 
Możemy więc zadać pytanie o zwierzęcą podmiotowość i dzięki temu dostrzec w dziele coś innego niż wtedy, gdy nasze główne pytania interpretacyjne wraz z samą kategorią podmiotu są zorientowane antropocentrycznie.

W wypadku niektórych dzieł wchodzi w grę szczególny aspekt omawianego problemu: sztuka może być narzędziem budowania podmiotowości przez ekspozycję uprzedmiotowienia. Podmiotowość może zostać uwidoczniona dzięki przedstawieniu jej opozycji, np. scen okrucieństwa wobec zwierząt. Istotne jest zatem odróżnienie statusu zwierzęcia w rzeczywistości przedstawionej od jego statusu w dziele. Artystyczna reprezentacja sceny uprzedmiotowienia jako tematu dzieła sztuki przyczynia się bowiem do ważności zwierzęcia, do uczynienia z niego bohatera dzieła i skupienia uwagi widza na sytuacji zwierzęcia, na jego przeżyciach lub po prostu na jego istnieniu, przez co zwierzę zyskuje podmiotowość właśnie w sferze sztuki.

Jak wspomniałam wcześniej, odbiór takich obrazów zmienia się - sytuacja zwierząt $\mathrm{w}$ przedstawionej rzeczywistości mogła być usankcjonowana społecznie w czasach artysty i w tym sensie normalna, lecz obecnie wyda nam się pełna okrucieństwa. A zatem dalszy proces upodmiotowienia zwierzęcia dokonuje się w postrzeganiu dzieła - zależnym od naszej zbiorowej i indywidualnej wrażliwości na los zwierząt - np. sceny rzezi lub polowania. Niemniej sam fakt ukazania zwierzęcych postaci w dziele jest elementem procesu ich upodmiotowienia w sztuce - obecność w dziele to niejako pierwszy warunek potencjalnego zaistnienia podmiotowości. Bez uznania zwierząt za warte przedstawienia i bez ich pokazania możliwości ustanawiania podmiotowości tych istot w sztuce są zazwyczaj zamknięte. Wyjątek może stanowić praca konceptualna, która przywoła zwierzęta w inny sposób niż za pomocą obrazowania.

Aby wykorzystać otwarte przez samą obecność zwierząt w dziełach sztuki możliwości dostrzegania zwierzęcej podmiotowości, trzeba unikać antropocentryzmu jako narzędzia budowania ontycznej przepaści między ludźmi a nie-ludzkimi zwierzętami, prowadzącego do tworzenia redukcjonistycznych teorii i ograniczającego pole interpretacji ${ }^{35}$. Można zamiast tego „pozostawić słowom elastyczność i rozpiętość konceptualną, choćby się miało to wiązać z zapisywaniem ich w cudzysłowie, aby zostawić maksimum potencjalności zwierzętom" "36, biorąc przy tym pod uwagę wciąż ograniczony, lecz bardzo szybko postępujący stan badań przyrodniczych nad zdolnościami kognitywnymi zwierząt nie-ludzkich. „Należy wystrzegać się wychodzenia od idei (zbyt) dobrze zdefiniowanych, ograniczonych, żeby móc je następnie weryfikować $[\ldots]^{\prime 37}$. Także w sztuce można się zatem otworzyć na zdecentralizo-

\footnotetext{
É. Baratay, op.cit., s. 47, 50.

6 Ibidem, s. 52.

37 Ibidem.
} 
wane, poszerzone interpretacje dzieł ${ }^{38}$ przez dostrzeganie w nich zwierząt jako postaci, nawet tych uznawanych dotychczas za marginalne, będące jedynie dopełnieniem, tłem, częścią krajobrazu lub atrybutem.

Anulowanie antropocentryzmu w znaczeniu uniknięcia ludzkiej perspektywy jest prawdopodobnie niemożliwe $\mathrm{z}$ uwagi na ograniczenia cielesne człowieka i naturę jego umysłu. Można jednak wyjść poza antropocentryzm w tym sensie, że nie uważa się człowieka za jedyny punkt odniesienia dla spraw ważnych, uznaje się natomiast samodzielną wartość zwierząt, czyli nie przypisuje się im wartości tylko przez wzgląd na ich powiązania z człowiekiem. Może się to dokonywać zarówno w sferze tematyki dzieł, jak i samej ich percepcji. Zoocentryzm jako alternatywa wobec antropocentryzmu oznacza analizę dzieł, która sytuuje zwierzęta w centrum zainteresowania. $Z$ takiej perspektywy tym, co w danym dziele ważne, są zwierzęta widziane zawsze jako istoty żywe lub reprezentanci istot żywych. Nie jest ona wyczerpująca, pozwala jednak poszerzyć kontekst możliwych interpretacji.

\section{Użycie prawdziwych zwierząt w sztuce}

Wypchane ciała zwierząt zaczęły być używane jako eksponaty od XVII wieku, głównie w kolekcjach naturaliów i gabinetach osobliwości. W XIX wieku upowszechniły się w naukowych i rozrywkowo-humorystycznych dioramach oraz narracyjnych makietach $\mathrm{z}$ antropomorfizowanymi zwierzętami odgrywającymi scenki z ludzkiego życia. Do sztuki wysokiej ciała zwierząt zostały jednak wprowadzone dopiero w drugiej połowie XX stulecia, a ich użycie cały czas się upowszechnia.

Już w starożytności zwierzęta angażowano do wielu działań o charakterze rozrywkowym, niekiedy graniczących ze sztuką: do różnego rodzaju widowisk, sportów, walk. Niemniej pisząc o performansie, mam na myśli podejmowane przez artystów działania, które uznawane są za sztukę przez muzea i galerie oraz rozpoznawane jako sztuka w środowisku twórców, krytyków i kuratorów. Zaangażowanie żywych zwierząt do tzw. sztuki wysokiej nastąpiło dopiero w drugiej połowie XX wieku i miało olbrzymie znaczenie dla zmiany ich statusu W sztuce oraz dla rozumienia samej sztuki - jej definicji, granic, form wyrazu. Było też istotne ze względu na zwierzęta jako istoty żywe: bezpośrednio dotyczyło jednostek zaangażowanych w działania artystyczne, a pośrednio mogło dotyczyć postrzegania całego gatunku lub nawet wszystkich zwierząt. Dokonywało się to zarówno przez sam fakt wykorzystania ich w sztuce lub zaangażowania ich do uczestniczenia $\mathrm{w}$ działaniach artystycznych, jak i przez tematy dzieł - treści trafiające do widzów.

\footnotetext{
38 Ibidem, s. 50, 52.
} 
Bezpośrednie użycie w sztuce prawdziwych zwierząt było radykalną zmianą ich statusu. $Z$ jednej strony stanowiło krok w kierunku ich upodmiotowienia poprzez stawianie ich na pozycji uczestnika, aktora lub nawet współtwórcy, z drugiej zaś umożliwiło skrajne uprzedmiotowienie w postaci zabijania dla sztuki i używania zwierzęcego ciała jako tworzywa artystycznego. Obie te tendencje zagościły na stałe w sztuce i nieustannie się nasilają. Zwierzęta zaczęły zatem funkcjonować nie tylko w obszarze reprezentacji, lecz także bezpośrednio, rzeczywiście i cieleśnie, co stanowiło ogromną zmianę w możliwych sposobach postrzegania ich podmiotowego statusu w sztuce. Użycie żywych zwierząt do performance'u lub instalacji niesie ze sobą potencjał skrajnego uprzedmiotowienia przez wykorzystanie, skrzywdzenie, narażenie na dyskomfort, stres, cierpienie, a nawet tortury lub zabicie rzeczywistej istoty żywej. W tym miejscu otwiera się pole do etycznych analiz kładących na szali podmiotowość zwierząt i wolność sztuki. Jednocześnie włączenie zwierząt do działań artystycznych i, jak to się często zdarzało, umieszczanie ich przez artystę w roli uczestników, aktorów lub nawet współtwórców są gestami podmiotowego traktowania lub upodmiotowienia w dziele i za sprawą dzieła. Zwierzęta stawały się sprawcami, a więc podmiotami (artystycznego) działania. Sprawczość zaś wielu badaczy uznaje za konstytutywną cechę podmiotu. Wspomniany wcześniej Uexküll już w latach trzydziestych pisał, że

[...] istota żywa, ujmowana jako podmiot, tworzy punkt centralny swojego wokółświata, wyposażając go w obiektywne własności, zgodnie ze swoimi subiektywnymi zdolnościami. Zakreślenie i podział przestrzeni zależy przede wszystkim od narządów zmysłów podmiotu. [...] Rzeczywiste uformowanie postrzeganych rzeczy w przedmioty następuje jednak dopiero w działaniu podmiotu, które podejmuje on w stosunku do nich. [...] Każdy podmiot znajduje się więc w swoim wokółświecie, w którym planowo wyzwalają się jego postrzeganie i działanie ${ }^{39}$.

W sztuce z udziałem zwierząt zazwyczaj można zaobserwować pewną oddzielność faktycznego wymiaru pracy, w którym zwierzę jest sprawcą i znacząco wpływa na kształt dzieła w wymiarze formalnym, plastycznym, estetycznym, wizualnym (także nieintencjonalnie, przez samą swoją obecność), od wymiaru symbolicznego, w którym aktywność, zachowania i wybory zwierzęcia są uwikłane w ludzką narrację, w kulturowe znaczenia, lecz zostaje ono w tym zakresie pozbawione sprawstwa, a nawet zmanipulowane, zinstrumentalizowane. Często jednak instrumentalizacja wychodzi poza sferę symboliczną, jest dosłowna i cielesna, stając się niekiedy uprzedmiotawiającą przemocą wobec istot żywych. Częścią sztuki stała się więc sama przemoc, a nie jedynie jej reprezentacja. Pisząc o tym, że w ciągu ostatnich dziesięcioleci na dużą skalę zaczęto używać nie tylko wizerunków zwierząt, lecz także

\footnotetext{
39 J. von Uexküll, op.cit., s. 19-22.
} 
samych zwierząt (z pewnością nie tylko w kontekście symbolicznym), Steve Baker zaznacza, że sztuka ta często bywa etycznie niepokojąca lub kontrowersyjna, lecz równie często tworzona jest przez artystów z pełną świadomością ponoszenia odpowiedzialności za zwierzęta prezentowane lub reprezentowane w ich pracach ${ }^{40}$.

John Simons w książce Animal Rights and the Politics of Literary Representation, pisząc o pracach artystycznych, do których stworzenia zostało użyte martwe ciało zwierzęce (lub jego fragment), lecz które są, przynajmniej w intencji twórcy, symboliczne, nie mówią o zwierzętach lub nie mówią przede wszystkim o nich, apeluje o uważniejszą percepcję. Uważa, że widz powinien dostrzec śmierć zwierzęcia oraz to, że „,człowiek używa jego pokawałkowanego ciała po to, by coś powiedzieć lub czymś się stać”41. Takie prace opierają się więc na założeniu, że zwierzę dla nas, ludzi, jest po to, byśmy mogli go używać, tym samym traktując je przedmiotowo. Jeżeli z takich prac cokolwiek miałoby wynikać dla zwierząt, to najwyżej dostrzeżenie przez odbiorcę faktu, że któreś $\mathrm{z}$ nich zostało zabite i wykorzystane ${ }^{42}$. Również w wypadku tych dzieł dostrzeżenie uprzedmiotowienia może więc sprawić, że zwierzę zostanie upodmiotowione w procesie odbioru, choćby zupełnie niezgodnym z pierwotną intencją artysty, jeśli chodzi o temat dzieła. Zauważając w takich pracach przede wszystkim martwe ciało, będące znakiem zakończonego życia zwierzęcej jednostki, dokonujemy upodmiotowienia zwierzęcia.

\section{Symbolika i instrumentalizacja}

Perspektywa zoocentryczna związana jest więc z koniecznością zerwania $\mathrm{z}$ postrzeganiem obecności zwierząt $\mathrm{w}$ sztuce wyłącznie w sferze symbolicznej, metaforycznej, operacyjnej i z umieszczeniem tej obecności w innym układzie odniesienia. Miejsce zwierzęcia w dziele sztuki określa się wówczas przez odniesienie do zwierzęcia jako istoty żywej, zarówno w gatunkowej naturze warunkującej jego moralnie istotne cechy dystynktywne oraz interesy, jak i w zwierzęcej jednostkowości, kluczowej dla podmiotowego statusu. Postrzeganie zwierzęcia wyłącznie jako reprezentanta gatunku - z pominięciem jego jednostkowego statusu - uniemożliwia widzenie go jako doświadczającego i przeżywającego sprawczego podmiotu. Jednocześnie jednostkowa tożsamość zwierzęcia jest warunkowana przez jego cechy gatunkowe, które

40 S. Baker, ,, You Kill Things to Look at Them”: Animal Death in Contemporary Art [w:] Killing Animals, Urbana-Chicago 2006, s. 70.

41 J. Simons, Animal Rights and the Politics of Literary Representation, BasingstokeNew York 2002, s. 207, 181-182, cyt. za: S. Baker, ,, You Kill Things...”, s. 70-71.

42 Por. ibidem. 
mogą determinować, wspomniane w pierwszej części tekstu, wymiary i zakresy podmiotowości związane ze zróżnicowanymi zdolnościami poznawczymi organizmów żywych.

Kiedy widzimy na obrazie wizerunek np. lisa, możemy się zastanawiać, jakiego lisa on przedstawia, co oznacza znak, którym jest ten wizerunek. Czy lis na obrazie reprezentuje wszystkie lisy, a zatem gatunek w jego zbiorowej podmiotowości? A może tylko tego konkretnego lisa, który został sportretowany? Być może jednak ów wizerunek oznacza coś innego, np. jest metaforą pewnych cech ludzkiego charakteru, z którymi tradycyjne asocjacje wiążą ten gatunek ${ }^{43}$ ? Jak piszą Landes, Young Lee i Youngquist, zwierzęta nigdy nie istnieją tylko po to, by zostały po prostu zobaczone, odczute, poznane. Historia gdzieś je umieszcza, kultura je zagarnia, używa ich, nauka je definiuje w pewien sposób, uczuciowość $\mathrm{w}$ inny ${ }^{44}$. Jedną z podstawowych cech omawianych przedstawień jest ich symboliczność. Symboliczny, alegoryczny lub metaforyczny charakter wizerunków zwierząt wiąże się z ich miejscem w porządku świata i potwierdza wspomniany wcześniej antropocentryczny charakter tego porządku. Baratay pisze, że zwierzę, jako najbliższa człowiekowi istota żywa, może zostać pomyślane symbolicznie, stanowi narzędzie oznaczenia i prze$\mathrm{kazu}^{45}$. Symboliczne przedstawienie oddala jednak od prawdy historycznej o zwierzęciu, nie opowiada bowiem jego historii, lecz historię czegoś innego jakiegoś wymiaru ludzkiej egzystencji lub jakiejś idei.

Rachel Poliquin w książce The Breathless Zoo: Taxidermy and the Cultures of Longing, analizując alegoryczne narracje $\mathrm{z}$ użyciem wypchanych zwierząt, zauważa, że widać w nich nie tyle gatunki zwierząt, ile ciemne, złośliwe odzwierciedlenie ludzkich pragnień, tęsknot i lęków. W alegorii w zasadzie zawsze to, co kulturowe, jest przed tym, co naturalne. Wyobrażeniowy potencjał alegorii tkwi w jej pozamaterialnym znaczeniu, poza jakąkolwiek wiedzą, która mogłaby zostać wyrażona za pomocą prostego opisu fizycznych form i własności. Przeobrażenie ludzkich pragnień przez materialność zwierzęcego ciała ujawnia wiele na temat nas samych, lecz często niewiele na temat samych zwierząt ${ }^{46}$.

Steve Baker stwierdza, że mówienie o martwych ciałach zwierząt w sztuce postmodernizmu w kategoriach „symbolicznej wagi” (symbolic weight) nastręcza trudności, ponieważ jedną z charakterystycznych cech tej sztuki jest unikanie symbolizmu ${ }^{47}$. Wydaje mi się jednak, że symbolika nadal pozostaje w niej obecna, tyle tylko, że zboczyła z tradycyjnych ścieżek symboliki okreś-

43 Por. J.B. Landes, P. Young Lee, P. Youngquist, op.cit., s. 3.

44 Ibidem, s. 3.

45 É. Baratay, op.cit., s. 16.

46 R. Poliquin, The Breathless Zoo: Taxidermy and the Cultures of Longing, Pennsylvania 2012, s. 174.

47 S. Baker, ,, You Kill Things...”, s. 78. 
lonych gatunków wypracowanej w sztuce nowożytnej głównie na podstawie dziedzictwa antycznego i chrześcijańskiego, średniowiecznych i nowożytnych tradycji świeckich oraz obserwacji przyrody. W sztuce postmodernistycznej nie chodzi już o tradycyjne odniesienia, lecz o sytuację, w której zwierzę znaczy coś innego niż ono samo. Według Sue Coe sytuacja, taka jest odarciem tego zwierzęcia z tożsamości, a co za tym idzie - przeoczeniem jego interesów ${ }^{48}$. Baker - powołując się na określenia Elaine Scarry, która pisała o patrzeniu na zranione lub martwe ciała ludzkie - nazywa to efektem przydawania realności przez otwarte ciało pracujące na rzecz innego zestawu przekonań ${ }^{49}$.

Zyskiwanie przez zwierzęta podmiotowości w sztuce wiąże się więc $z$ odejściem od symboliki. Niesymboliczne przedstawienia i niesymboliczne interpretacje są bliższe postrzeganiu zwierząt jako podmiotów. Proces upodmiotowienia dokonuje się m.in. na poziomie semiotycznym, a polega na tym, że żywe stworzenia stają się desygnatami samych siebie - wizerunek zwierzęcia oznacza właśnie zwierzę lub głównie zwierzę, a nie przypisaną mu przez człowieka abstrakcyjną wartość symboliczną.

Symboliczne przedstawienie jest instrumentalizacją wizerunku na potrzeby sztuki. Instrumentalizacja to antypodmiotowość, ale użycie tego wizerunku nie musi oznaczać instrumentalizacji samego zwierzęcia. W performansie, filmie i fotografii na pewnym poziomie żywe stworzenie wydaje się tożsame z jego wizerunkiem, gdyż zostaje ono bezpośrednio pokazane lub zarejestrowane kamerą. Inaczej rzecz ujmując, wizerunek na ekranie okazuje się w tym przypadku wyjątkowo bliski rzeczywistemu zwierzęciu, ponieważ w procesie powstawania dzieła doszło do utożsamienia żywego stworzenia z jego reprezentacją. Sfilmowana krzywda (o ile to nie gra, mistyfikacja) jest zatem na pewnym poziomie tożsama z rzeczywistą krzywdą. Użycie zwierzęcia w sztuce nie zawsze jednak musi wiązać się z krzywdą i być sprzeczne $z$ jego interesami. Nie musi go uprzedmiotawiać, a niekiedy nawet służy ukazaniu jego podmiotowości poprzez wyeksponowanie jednostkowości, ontycznego statusu, wartości jego istnienia, przeżyć i doświadczeń, narodzin, śmierci, radości życia.

48 Cyt. za: ibidem.

49 S. Baker, ,, You Kill Things...”, s. 81. Elaine Scarry pisze o zranionym, wypełnionym bólem lub martwym ciele ludzkim w perspektywie dużo szerszej niż artystyczna. Baker odnosi jej spostrzeżenia do ciał zwierząt w sztuce. Fragment, który przywołuję za Bakerem, u Scarry brzmi tak: „When the referential direction is by proximity or juxtaposition, what is proximate, what is juxtaposed can be changed: a different symbolic counterpart or cultural fragment can be placed beside the wound whose compelling reality may now work on behalf of the different constellation of beliefs clinging to the new fragment" (E. Scarry, The Body in Pain: The Making and Unmaking of the World, New York-Oxford 1985, s. 119). 
Instrumentalizacja $\mathrm{w}$ dziele sztuki może się odbywać w wymiarze symbolicznym, kiedy mamy do czynienia z manipulacją wizerunkiem. Dokonuje się ona tylko w zakresie znaczenia dzieła, a więc nie dotyka bezpośrednio zwierzęcia, jakkolwiek może mieć pośredni związek ze stosowaną wobec niego przemocą, gdyż sankcjonuje i odzwierciedla instrumentalne podejście, bagatelizując funkcjonowanie zwierzęcia jako istoty ontologicznie ważnej - przez sam fakt, że istnieje. Instrumentalizacją wizerunku jest też antropomorfizacja. Zwierzęta wykonują czynności inspirowane ludzkimi zachowaniami, zwyczajami, nadziejami i lękami, są bohaterami opowieści o ludziach, nie o sobie. Paradoksalnie wtedy na pewnej płaszczyźnie antropomorfizacja czyni zwierzęta postaciami, osobami, ludźmi, a więc je upodmiotawia w sposób jednoznaczny - nadając im jednak ludzką, a nie zwierzęcą podmiotowość. Mimo to świadome zastosowanie antropomorfizacji jako narzędzia krytycznego wobec antropocentryzmu może być sposobem poszukiwania zwierzęcej podmiotowości, jak np. w filmie Kathy High Lily Does Derrida: A Dog's Video Essay ${ }^{50}$, w którym suczka Lily (uznana przez High za współautorkę filmu) staje się podmiotem egzystencjalnej tragedii, a jednocześnie mówi: „Wiem, pomyślicie, że to jest antropomorfizowanie mnie...".

\section{$* * *$}

Powyższym cytatem przywołałam na zakończenie jedyną w tym tekście wymienioną $\mathrm{z}$ tytułu pracę artystyczną, a jednocześnie zasygnalizowałam kwestię, która wymaga rozwinięcia $\mathrm{w}$ osobnym artykule. Coraz częstsze świadome odwołania artystów do teorii naukowych lub filozoficznych, jak w przypadku wspomnianego filmu, w którym suka Lily rozkłada na części pierwsze esej Jacques'a Derridy The Animal That Therefore I Am ${ }^{51}$, wymagają zagłębienia się podczas interpretacji prac artystycznych w konkretne koncepcje zwierzęcej podmiotowości.

Również analiza wykorzystania prawdziwych zwierząt jako uczestników sztuki nie tylko wiąże się z koniecznością opisu i interpretacji przez pryzmat wspomnianych na początku teorii filozoficzno-etycznych dotyczących zwierząt jako istot żywych, lecz także wymaga zbadania faktograficznej warstwy dzieł w celu dowiedzenia się, kim były zaangażowane w proces twórczy zwierzęta, co się z nimi działo i co mogły przeżywać. Sztuka, rozszerzając swe granice, zagarniając i przetwarzając istoty żywe, formy obcowania z nimi, ich życia, ciała i śmierci, zatarła granice między tym, co artystyczne i pozaartystyczne, przez co kategorie postrzegania zwierząt $w$ jej ramach zbliżyły się do postrzegania zwierząt poza nią, także pod względem etycznym i prawnym.

Niniejszy tekst, zgodnie z założeniami redaktorów tego numeru „Wielogłosu”, jest próbą czysto teoretycznego ujęcia problemu. Zrezygnowałam

50 Zob. http://kathyhigh.com/video-lily-does-derrida.html [dostęp: 1.06.2018].

51 J. Derrida, op.cit. 
z odniesień do konkretnych dzieł artystycznych, aby artykuł nie stał się studium przypadku oraz aby nie sprowadzać dzieł sztuki do czystej egzemplifikacji. Mam nadzieję, że przysłuży się sztuce i zwierzętom, pozostawiając zagadnienie zwierzęcej podmiotowości otwartym, na skrzyżowaniu sztuki i życia.

\section{Bibliografia}

Abbott A., Octopus Genome Holds Clues to Uncanny Intelligence, „Nature”, 12.08.2015, https://www.nature.com/news/octopus-genome-holds-clues-to-uncanny-intelligence-1.18177 [dostęp: 14.05.2018].

Aloi G., Art and Animals, London-New York 2012.

The Animal Ethics Reader, eds. S.J. Armstrong, R.G. Botzler, Abingdon-New York 2008.

Animal Philosophy: Ethics and Identity, eds. P. Atterton, M. Calarco, London-New York 2011.

Baker S., Artist/Animal, Minneapolis-London 2013.

Baker S., The Postmodern Animal, London 2000.

Baker S., ,, You Kill Things to Look at Them”: Animal Death in Contemporary Art [w:] Killing Animals, Urbana-Chicago 2006.

Baratay É., Zwierzęcy punkt widzenia. Inna wersja historii, przeł. P. Tarasewicz, Gdańsk 2014.

Bekoff M., Meaney C.A., Encyclopedia of Animal Rights and Animal Welfare, Westport, CT 1998.

Bentham J., Wprowadzenie do zasad moralności i prawodawstwa, przeł. B. Nawroczyński, Warszawa 1958.

Białocerkiewicz J., Status prawny zwierzat. Prawa zwierząt czy prawna ochrona zwierząt, Toruń 2005.

Braidotti R., Etyka stawania się niewykrywalnym, przeł. J. Bednarek [w:] Teorie wywrotowe. Antologia przekładów, red. A. Gajewska, Poznań 2012.

Braidotti R., Po człowieku, przeł. J. Bednarek, A. Kowalczyk, Warszawa 2014.

Braidotti R., The Posthuman, Cambridge-Malden 2013.

Broglio R., Surface Encounters: Thinking with Animals and Art, Minneapolis-London 2011.

Calarco M., Thinking Through Animals: Identity, Difference, Indistinction, Stanford 2015.

Calarco M., Zoographies: The Question of the Animal from Heidegger to Derrida, New York 2008.

Carruthers P., Animal Subjectivity, „PSYCHE”, April 1998, no. 4 (3).

Carruthers P., Suffering without Subjectivity, „Philosophical Studies” 2004, vol. 121, no. 2 . 
Castriciano J., Animal Subjects: An Ethical Reader in a Posthuman World, Ontario 2008.

Derrida J., The Animal That Therefore I Am, ed. M.-L. Mallet, trans. D. Wills, New York 2008.

Donaldson S., Kymlicka W., Zoopolis: A Political Theory of Animal Rights, New York 2011.

Elżanowski A., Pietrzykowski T., Zwierzęta jako nieosobowe podmioty prawa, „Forum Prawnicze", luty 2013.

Francione G.L., Animal Rights and Animal Welfare, New York 2005.

Francione G.L., Animals, Property, and Law, Philadelphia 1995.

Grazia D. de, O byciu osoba poza gatunkiem Homo sapiens [w:] W obronie zwierzat, red. P. Singer, przeł. M. Betley, Warszawa 2011.

Haraway D., Manifest gatunków stowarzyszonych, przeł. J. Bednarek [w:] Teorie wywrotowe. Antologia przekładów, red. A. Gajewska, Poznań 2012.

Landes J.B., Young Lee P., Youngquist P., Introduction [w:] Gorgeous Beasts: Animal Bodies in Historical Perspective, eds. J.B. Landes, P. Young Lee, P. Youngquist, Pennsylvania 2012.

Poliquin R., The Breathless Zoo: Taxidermy and the Cultures of Longing, Pennsylvania 2012.

Probucka D., Filozoficzne podstawy praw zwierząt, Kraków 2013.

Regan T., The Case for Animal Rights, Philadelphia 1983.

Regan T., Defending Animal Rights, Urbana-Chicago 2001.

Scarry E., The Body in Pain: The Making and Unmaking of the World, New YorkOxford 1985.

Simons J., Animal Rights and the Politics of Literary Representation, BasingstokeNew York 2002.

Singer P., Wyzwolenie zwierząt, przeł. A. Alichniewicz, A. Szczęsna, Warszawa 2004.

Uexküll J. von, Biologia lub fizjologia, przeł. A. Pobojewska, M. Półrola, „Przegląd Filozoficzno-Literacki” 2011, nr 2-3 (31).

Wolfe C., In the Shadow of Wittgenstein's Lion: Language, Ethics, and the Question of the Animal [w:] Zoontologies: The Question of the Animal, ed. C. Wolfe, Minneapolis-London 2003. 